\title{
Optimization System of Coalbed Methane (CBM) Horizontal Well Types and Engineering Technology Modes in southern Qinshui Basin, China
}

\author{
Qingzhong Zhu ${ }^{1, \text { a }}$, Shu Tao, b , Longwei Chen ${ }^{1, \mathrm{c}}$, Yanhui Yang ${ }^{1}$, Shumin Lang ${ }^{1}$, \\ Liwen Zhang ${ }^{1}$ \\ ${ }^{1}$ PetroChina Huabei Oilfield Company, Renqiu Hebei, 062552, China \\ ${ }^{2}$ School of energy resources, China University of Geosciences (Beijing), Beijing, 100083, China \\ a cyy_zqz@petrochina.com.cn, ${ }^{b}$ cugbst@126.com, ${ }^{c}$ yjzx_clw@petrochina.com.cn
}

Keywords: horizontal well; well type; optimization system; engineering technology mode; CBM Abstract: To optimize the coalbed methane (CBM) horizontal well types in the southern Qinshui Basin, the optimization system of horizontal well types accompanied with corresponding engineering technology modes was established basing on the well type geology adaptability and key factors influencing the horizontal well productivity. Results show that, at present, two types of horizontal wells including single- ( $\mathrm{L}$ and $\mathrm{U}$ ) and multi- (V, herringbone and roof) branches are used in this basin. Under the targets of easier well completion, less pollution, and more benefit, the workflow of well type optimization is that: 1) determining the horizontal well development area with the coal structure; 2) extracting the vertical well development area by the vitrinite reflectance from the horizontal well development area; 3 ) determining the horizontal well types and engineering technology modes by considering the ratio of critical desorption pressure $\left(p_{\mathrm{c}}\right)$ to initial reservoir press $\left(p_{\mathrm{i}}\right)$ and in situ stresses. Seven engineering technology modes are put forward, namely production by vertical well with fracturing, joint production by vertical well with fracturing and horizontal well with staged fracturing, joint production by single- and multi-branch horizontal well with cave completion, production by multi-branch horizontal well, joint production by vertical well with fracturing and single-branch horizontal well, production by single-branch horizontal well with cave completion, and no production at the current stage.

\section{Introduction}

In recent decades, the southern Qinshui Basin has become the most important high-rank coalbed methane (CBM) base and achieved the CBM commercial exploitation ${ }^{[1]}$. But many features such as low pressure, low porosity, low permeability, low gas saturation, and strong anisotropy in the coal reservoir result in poor CBM development effects ${ }^{[2-4]}$. To obtain the expectant gas rate, the CBM workers referred to the enhanced recovery method of the vertical well applied in conventional oil and gas fields and then used the horizontal well for CBM development in the Qinshui Basin ${ }^{[5]}$. Although some results have been achieved, the conventional horizontal well is being difficult to meet the demands about the CBM industry with the continuous improvements of horizontal well technologies and the knowledge of the geological conditions. In the same reserve area, the burial depth of the coal and the pressure system are different as well as the transverse distributions of the physical properties, gas content, and critical desorption pressure, while some problems of the coal seam collapse during the drilling process and powdered coal blocking usually appear which lead to the expectant target can't be obtained with horizontal wells directly ${ }^{[6-8]}$. Thus, to gain the CBM production maximization, except for the high quality reservoir, reasonable engineering designs are necessary and the well type determination is the most basic in the well optimization ${ }^{[9]}$. Here, the southern Qinshui Basin was taken as an example, the geology adaptability of horizontal well types was compared and the optimization system of CBM horizontal well types accompanied with corresponding engineering technology modes was established in combination with the key factors influencing the horizontal well productivity, which is helpful for the CBM high-efficient development. 


\section{Horizontal well types and comparison of the geology adaptability}

\section{Horizontal well types}

Currently, the horizontal well types applied in the southern Qinshui Basin could be divided into two types: single- and multi-branch wells. Since different horizontal wells have different geology adaptabilities, well control areas, and capitalized costs, the actual applications of the horizontal well types have to consider various factors.

1) Multi-branch horizontal well

Multi-branch horizontal wells include three types: V shape, herringbone, and roof horizontal well. The $\mathrm{V}$ shape well has large well control area and high CBM production. However, this kind of multi-branch well with long drilling time and high cost needs perfect reservoir and faces great completion risks in complex tectonic areas. Moreover, the wellhole is easy to be collapsed during gas production and difficult to be maintained. Fig. 1(a) is the schematic diagram of the V shape horizontal well. Later, the herringbone horizontal well with steel casing pipe in principal branches and PE screen pipe in branches was invented which is simple and could be controlled (Fig. 1(b)). When CBM is developed via this well type, the staged fracturing is usually combined and in the late production stage, the herringbone well could be reentered, maintained, and operated ${ }^{[10]}$. Meanwhile, aiming at the problem of wellhole collapse, the roof horizontal well was created, namely the principal branches extend in the roof, branches in the boundary between the coal seam and roof, and the vein branches in coal seams (Fig. 1(c)). The advantages of this well type are easier well completion, larger well control area, longer horizontal footage while it occupies more well sites and requires higher quality roof and other geology conditions ${ }^{[11]}$.

2) Single-branch horizontal well

The single-branch horizontal wells mainly include $\mathrm{L}$ and $\mathrm{U}$ shape wells. The former assembles the engineering well and the cavern well with PE screen pipe completion (Fig. 1(d)). The well type, production technology, and well spacing are simple and flexible. Usually, a U shape well produces CBM from multi-sets of coals and also has high control reserve and cost ${ }^{[12]}$. Compared to the $U$ shape well, the L shape horizontal well only has one well and could across more intrinsic fractures. The horizontal segment could be caved in many stages which are in favor of the stress relief and decreasing the reservoir damage from fracturing. Like herringbone well, in the late production stage, both the $\mathrm{U}$ and $L$ shape wells could be reentered, maintained, and operated ${ }^{[13]}$. According to the attitude of stratum, the L shape well could be divided into up and downdip wells (Figs. 1(e) and 1(f)).

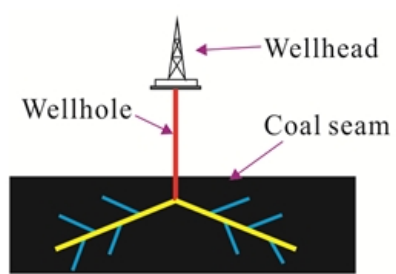

(a) V shape multi-branch horizontal well

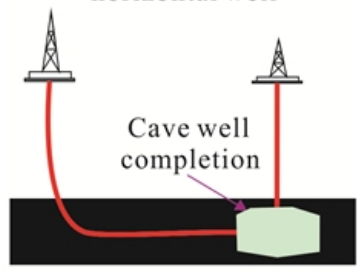

(d) U shape single-branch horizontal well

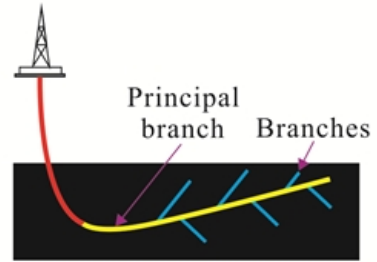

(b) Herringbone multi-branch horizontal well

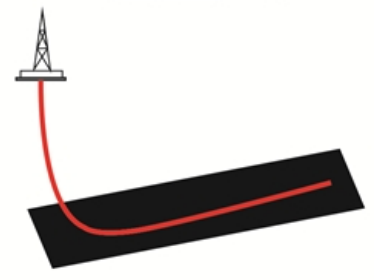

(e) L shape single-branch horizontal well (updip)

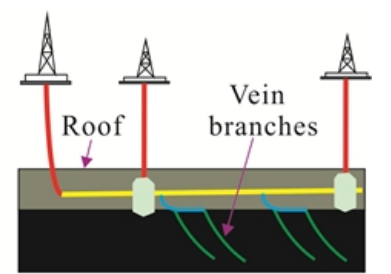

(c) Roof multi-branch horizontal well

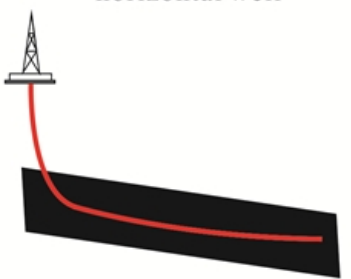

(f) L shape single-branch horizontal well (downdip)

Fig. 1 Schematic diagram of the horizontal well types

\section{Comparison of the geology adaptability for different horizontal wells}

Table 1 summarizes the geology adaptability of the two types of horizontal wells. On the whole, 
the single-branch horizontal wells have higher geology adaptability than that of the multi-branch wells. And the geology adaptability of the herringbone and roof horizontal wells is higher than that of the $\mathrm{V}$ shape well. From the current development trend of the horizontal well, namely low cost, maintainability, and low floor space, the L shape single-branch horizontal well is worthy being vigorously promoted (Table 1), while the other well types could be moderately promoted under appropriate geologic and economic conditions.

Table 1 Geology adaptability evaluation of the two types of horizontal wells

\begin{tabular}{|c|c|c|c|c|c|c|}
\hline \multirow{2}{*}{\multicolumn{2}{|c|}{ Well type }} & \multicolumn{3}{|c|}{ Multi-branch } & \multicolumn{2}{|c|}{ Single-branch } \\
\hline & & V shape & Herringbone & Roof & U shape & L shape \\
\hline \multicolumn{2}{|c|}{ Control area $\left(\mathrm{km}^{2}\right)$} & $0.5 \sim 0.8$ & $0.4 \sim 0.7$ & $0.5 \sim 0.8$ & $0.2 \sim 0.3$ & $0.2 \sim 0.3$ \\
\hline \multicolumn{2}{|c|}{ Cost (million yuan) } & 10 & 4 & 25 & 6.5 & 3 \\
\hline \multirow{2}{*}{$\begin{array}{c}\text { Geology } \\
\text { requirements }\end{array}$} & $\begin{array}{l}\text { Coal structure } \\
\text { Stratigraphic dip }\end{array}$ & \multirow{2}{*}{\multicolumn{3}{|c|}{$\begin{array}{c}\text { Primary } \\
\text { Monocline }\left(2 \sim 8^{\circ}\right) \\
\text { Complex }\end{array}$}} & \multicolumn{2}{|c|}{$\begin{array}{l}\text { Primary-cataclastic } \\
\text { Monocline }\left(8 \sim 20^{\circ}\right)\end{array}$} \\
\hline & Well site & & & & Complex & Simple \\
\hline \multirow{6}{*}{$\begin{array}{l}\text { Engineering } \\
\text { requirements }\end{array}$} & Completion & Open hole & Casing and screen pipes & Open hole & \multirow{2}{*}{\multicolumn{2}{|c|}{$\begin{array}{l}\text { Screen pipes } \\
\text { Good }\end{array}$}} \\
\hline & Stability & $\mathrm{Bad}$ & Good & Middle & & \\
\hline & Reenterability & No & Yes & No & \multicolumn{2}{|c|}{ Yes } \\
\hline & Alterationability & No & Yes & No & \multicolumn{2}{|c|}{ Yes } \\
\hline & Maintainability & No & Yes & No & \multicolumn{2}{|c|}{ Yes } \\
\hline & Production technology & High & Low & High & Middle & Low \\
\hline \multicolumn{2}{|c|}{ Evaluation result (promotion) } & & Moderate & & Moderate & Vigorous \\
\hline
\end{tabular}

\section{Establishment of optimization system for CBM horizontal well types}

The purpose of CBM horizontal well type optimization is to eliminate the uncertain factors when the conventional well type is evaluated and make the well type optimization process more clear and simple. In this work, the optimization system of CBM horizontal well types was established on the basis of the well type geology adaptability and the key factors which influence the horizontal well productivity. The targets are easier well completion, less pollution, and more benefit.

1) Limited by the success rate of well completion and fracturing technology, the primary and primary-cataclastic structure coals are the main CBM reservoir ${ }^{[6]}$. Thus, the precondition of the optimization is easier well completion. In other word, the primary and primary-cataclastic structure coals should be considered firstly where the former is more in favor of well completion.

2) From the perspective of less pollution and more benefit, the larger the ratio of critical desorption pressure to initial reservoir pressure $\left(p_{\mathrm{c}} / p_{\mathrm{i}}\right)$ is, the more easily the gas could desorb under the same pressure drop ${ }^{[2]}$. Meanwhile, higher $p_{\mathrm{c}} / p_{\mathrm{i}}$ could decrease the negative effect from the drilling and fracturing liquids ${ }^{[14]}$. Therefore, it is of great significance to use the $p_{\mathrm{c}} / p_{\mathrm{i}}$ as the minor parameter for well type determination. Fig. 2 shows that with 0.3 and 0.6 , the maximum gas rate per $100 \mathrm{~m}$ could be divided into three levels and lager $p_{\mathrm{c}} / p_{\mathrm{i}}$ contributes simpler development mode.

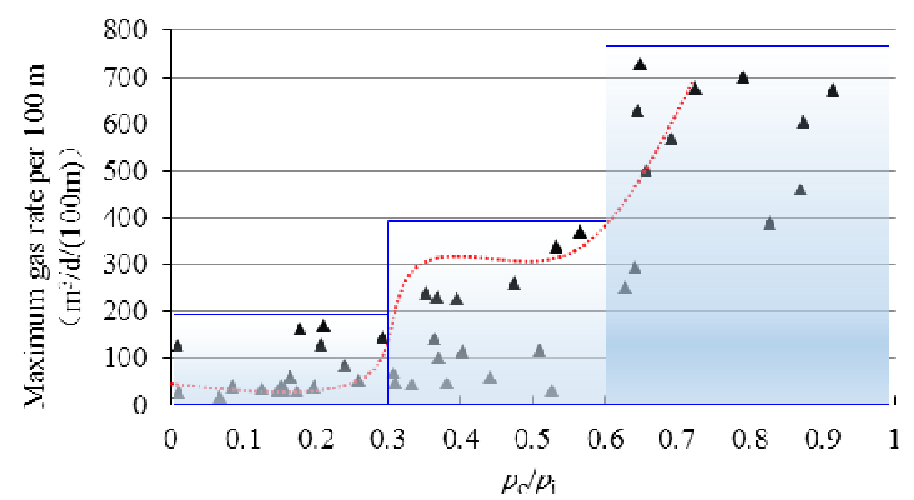

Fig. 2 Relationship of the $p_{\mathrm{c}} / p_{\mathrm{i}}$ and the maximum gas production rate per $100 \mathrm{~m}$

3) The high permeability is necessary for efficiency CBM development ${ }^{[1]}$ while the in situ stress could influence the development effect by controlling the permeability. The tension stress area usually 
has higher permeability ${ }^{[15]}$. So, in the tension stress area, the simple horizontal well could be adopted and the relative complex wells could be applied in the extrusion and balance stress areas.

In addition, when the vitrinite reflectance is larger than 3.8, the well number of the maximum gas rate per $100 \mathrm{~m}$ more than $200 \mathrm{~m}^{3} / \mathrm{d}$ increases obviously (Fig. 3(a)); although in these wells with the maximum gas rate more than $10000 \mathrm{~m}^{3} / \mathrm{d}$, the numbers of the vertical and horizontal wells are equivalent, the gas rate of the horizontal well is just two times than that of the vertical well (Fig. 3(b)). This phenomenon demonstrates that using vertical well could obtain more economic benefit. Fig. 4 describes the workflow of optimization for horizontal well types on the basis of the above results.
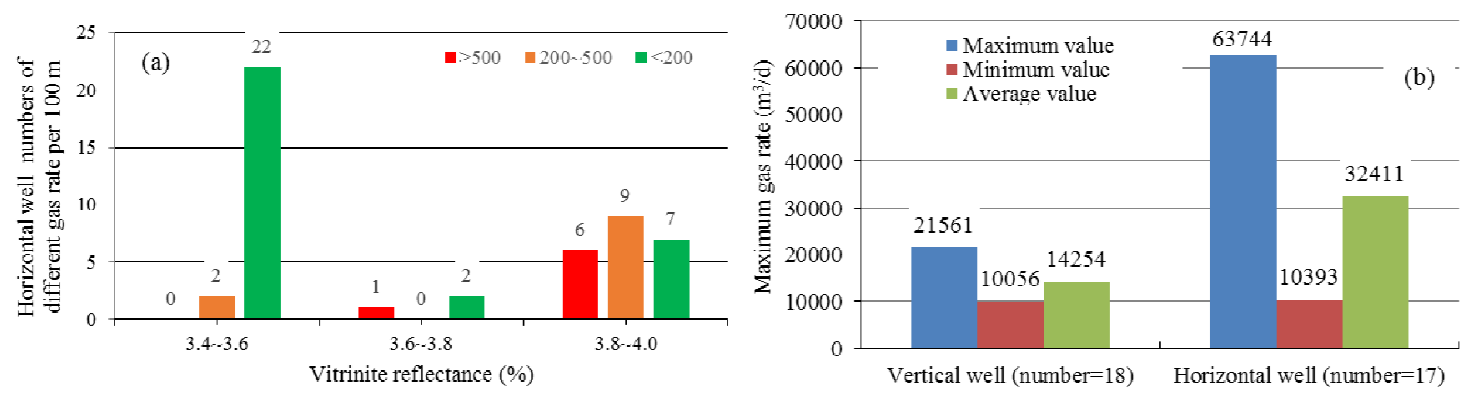

Fig. 3 Relationship of the vitrinite reflectance and the gas rate

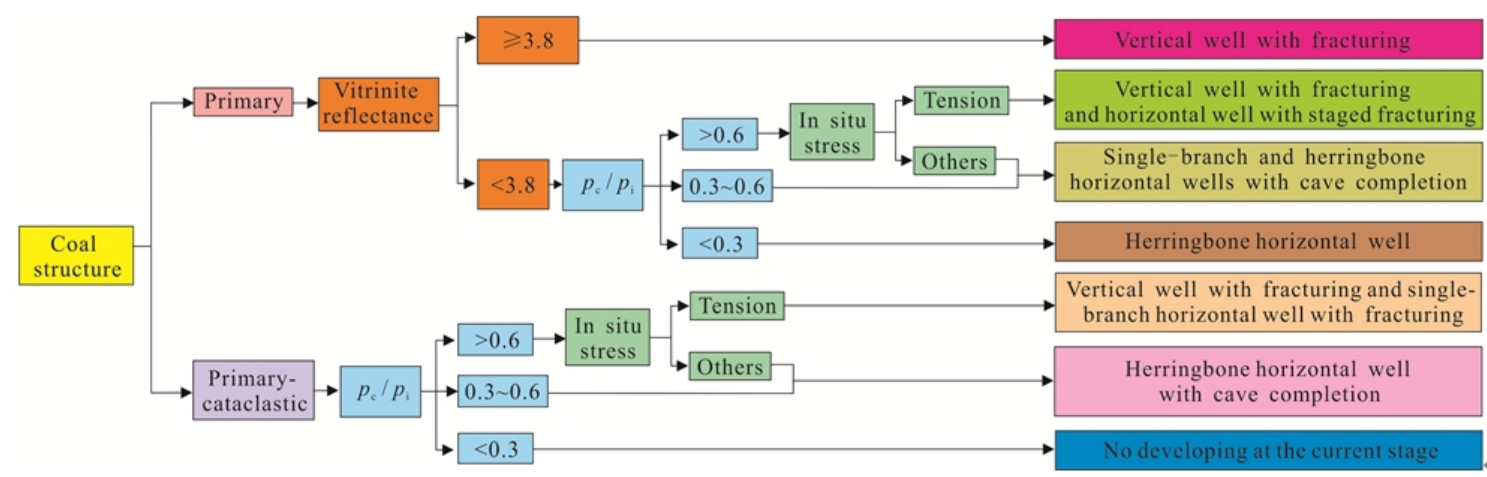

Fig. 4 Workflow flow of the horizontal well type optimization

\section{Engineering technology modes basing on the well type optimization}

Basing on the well type optimization system, seven development areas with corresponding engineering technology modes are put forward. By comparison with the vertical well from the similar area with the horizontal well, the work idea of from the optimization of geologic parameters to the engineering technology modes could be applied more widely.

\section{Production by vertical well with fracturing}

Mode 1 is production by vertical well with fracturing, which is applied in the primary structure coal with the vitrinite reflectance more than 3.8 (e.g. the west Duanshi area). Compared the gas rates of vertical and horizontal wells, the maximum gas rate of vertical well in the west Duanshi area is 21561 $\mathrm{m}^{3}$ averaging $9687 \mathrm{~m}^{3}$ while the maximum gas rate of horizontal well is $63503 \mathrm{~m}^{3}$ averaging $22531 \mathrm{~m}^{3}$. But the cost of horizontal well is more than vertical well (about 1.5 million yuan) and has the risk of wellhole collapse (Table 2). Thus, this area should adopt vertical well with fracturing.

Table 2 Comparison of CBM development indexes in the west Duanshi area

\begin{tabular}{ccccccc}
\hline $\begin{array}{c}\text { Well } \\
\text { name }\end{array}$ & $\begin{array}{c}\text { Coal } \\
\text { structure }\end{array}$ & $\begin{array}{c}p_{\mathrm{c}} \\
(\mathrm{MPa})\end{array}$ & $p_{\mathrm{c}} / p_{\mathrm{i}}$ & $\begin{array}{c}\text { Average gas } \\
\text { rate }\left(\mathrm{m}^{3} / \mathrm{d}\right)\end{array}$ & $\begin{array}{c}\text { Maximum gas } \\
\text { rate }\left(\mathrm{m}^{3} / \mathrm{d}\right)\end{array}$ & Well type \\
\hline Well 1 & & 2.90 & $\begin{array}{c}0.9 \\
5\end{array}$ & 40655 & 63503 & $\begin{array}{c}\text { Multi-branch } \\
\text { horizontal well }\end{array}$ \\
Well 2 & & 2.90 & $\begin{array}{c}0.9 \\
5\end{array}$ & 4408 & 10393 & \\
Well 3 & Primary & & $\begin{array}{c}0.6 \\
5\end{array}$ & 8075 & 15518 & $\begin{array}{c}\text { Vertical well with } \\
\text { fracturing }\end{array}$ \\
Well 4 & & 1.98 & $\begin{array}{c}5 \\
0.6\end{array}$ & 11299 & 21561 & \\
\hline
\end{tabular}




\section{Joint production by vertical well with fracturing and horizontal well with staged fracturing}

Mode 2 is joint production by vertical well with fracturing and horizontal well with staged fracturing, which is applied in the primary structure coal with the vitrinite reflectance less than 3.8 and $p_{\mathrm{c}} / p_{\mathrm{i}}$ more than 0.6 and tension stress (e.g. the Libi area). Compared the gas rates of fractured vertical well, horizontal well with staged fracturing, and multi-branch horizontal well, it could be seen that the gas rate of horizontal well with staged fracturing is the greatest and the value is about $3 \sim 5$ times than that of the other well types (Table 3). Thus, this area should adopt joint production by vertical well with fracturing and horizontal well with staged fracturing and the latter is more important.

Table 3 Comparison of CBM development indexes in the Libi area

\begin{tabular}{ccccccc}
\hline $\begin{array}{c}\text { Well } \\
\text { name }\end{array}$ & $\begin{array}{c}\text { Coal } \\
\text { structure }\end{array}$ & $\begin{array}{c}p_{\mathrm{c}} \\
(\mathrm{MPa})\end{array}$ & $\begin{array}{c}p_{\mathrm{c}} / p_{\mathrm{i}} \\
\text { Well 5 }\end{array}$ & $\begin{array}{c}\text { Average gas } \\
\text { rate }\left(\mathrm{m}^{3} / \mathrm{d}\right)\end{array}$ & $\begin{array}{c}\text { Maximum gas } \\
\text { rate }\left(\mathrm{m}^{3} / \mathrm{d}\right)\end{array}$ & Well type \\
Well 6 & & 4.33 & $\begin{array}{c}0.6 \\
3\end{array}$ & 6513 & 12529 & $\begin{array}{c}\text { L shape horizontal well with } \\
\text { staged fracturing }\end{array}$ \\
Well 7 & Primary & 4.29 & $\begin{array}{c}0.6 \\
3\end{array}$ & 10025 & 25298 & Multi-branch horizontal well \\
Well 8 & 3.59 & $\begin{array}{c}0.5 \\
5\end{array}$ & 2384 & 5266 & Vertical well with fracturing \\
\hline
\end{tabular}

\section{Joint production by single- ( $\mathrm{L}$ and $\mathrm{U})$ and multi- ( $\mathrm{V}$, herringbone and roof) branches horizontal} well with cave completion

Mode 3 is joint production by single- ( $\mathrm{L}$ and $\mathrm{U}$ ) and multi- (V, herringbone and roof) branches horizontal well with cave completion, which is applied in the primary structure coal with the vitrinite reflectance less than 3.8 and the $p_{\mathrm{c}} / p_{\mathrm{i}} 0.3 \sim 0.6$ and tension stress (e.g. the west Zhengzhuang area) or $p_{\mathrm{c}} / p_{\mathrm{i}}$ more than 0.6 and the extrusion and balance stresses. Compared the gas rates of vertical and horizontal wells in the west Zhengzhuang area, it could be seen that the gas rate of horizontal well is far more than that of the vertical well, which indicates that the vertical well is not appropriate in this area (Table 4). Thus, this area should adopt joint production by single- and multi- branches horizontal well with cave completion.

Table 4 Comparison of CBM development indexes in the west Zhengzhuang area

\begin{tabular}{ccccccc}
\hline $\begin{array}{c}\text { Well } \\
\text { name }\end{array}$ & $\begin{array}{c}\text { Coal } \\
\text { structure }\end{array}$ & $\begin{array}{c}p_{\mathrm{c}} \\
(\mathrm{MPa})\end{array}$ & $p_{\mathrm{c}} / p_{\mathrm{i}}$ & $\begin{array}{c}\text { Average gas } \\
\text { rate }\left(\mathrm{m}^{3} / \mathrm{d}\right)\end{array}$ & $\begin{array}{c}\text { Maximum gas } \\
\text { rate }\left(\mathrm{m}^{3} / \mathrm{d}\right)\end{array}$ & Well type \\
\hline Well 9 & & 3.14 & $\begin{array}{c}0.4 \\
7\end{array}$ & 4967 & 13588 & $\begin{array}{c}\text { Multi-branch } \\
\text { horizontal well }\end{array}$ \\
Well 10 & & 3.27 & $\begin{array}{c}0.5 \\
0\end{array}$ & 11977 & 20727 & \\
Well 11 & Primary & 2.66 & $\begin{array}{c}0.5 \\
1\end{array}$ & 175 & 403 & $\begin{array}{c}\text { Vertical well with } \\
\text { fracturing }\end{array}$ \\
Well 12 & & 3.82 & $\begin{array}{c}0.5 \\
5\end{array}$ & 191 & 683 & \\
\hline
\end{tabular}

\section{Production by multi- (V, herringbone and roof) branch horizontal well}

Mode 4 is production by multi- ( $\mathrm{V}$, herringbone and roof) branch horizontal well, which is applied in the primary structure coal with the vitrinite reflectance less than 3.8 and the $p_{\mathrm{c}} / p_{\mathrm{i}}$ less than 0.3 (e.g. the middle Zhengzhuang area). Compared the gas rates of multi-branch horizontal well and adjacent fractured vertical wells, the gas rate of horizontal well is much larger than the fractured vertical wells (Table 5). Thus, this area should adopt multi-branch horizontal well to produce CBM. 
Table 5 Comparison of CBM development indexes in the middle Zhengzhuang area

\begin{tabular}{|c|c|c|c|c|c|c|}
\hline $\begin{array}{r}\text { Well } \\
\text { name }\end{array}$ & $\begin{array}{c}\text { Coal } \\
\text { structure }\end{array}$ & $\begin{array}{c}p_{\mathrm{c}} \\
(\mathrm{MPa})\end{array}$ & $p_{\mathrm{c}} / p_{\mathrm{i}}$ & $\begin{array}{l}\text { Average gas } \\
\text { rate }\left(\mathrm{m}^{3} / \mathrm{d}\right)\end{array}$ & $\begin{array}{l}\text { Maximum gas } \\
\text { rate }\left(\mathrm{m}^{3} / \mathrm{d}\right)\end{array}$ & Well type \\
\hline Well 13 & \multirow{4}{*}{ Primary } & 2.10 & $\begin{array}{c}0.2 \\
8\end{array}$ & 2581 & 9288 & \multirow{2}{*}{$\begin{array}{l}\text { Multi-branch } \\
\text { horizontal well }\end{array}$} \\
\hline Well 14 & & 2.00 & $\begin{array}{c}0.2 \\
7\end{array}$ & 2050 & 11692 & \\
\hline Well 15 & & 2.36 & $\begin{array}{c}0.2 \\
9\end{array}$ & 81 & 400 & \multirow{2}{*}{$\begin{array}{l}\text { Vertical well with } \\
\text { fracturing }\end{array}$} \\
\hline Well 16 & & 2.20 & $\begin{array}{c}0.2 \\
9\end{array}$ & 35 & 68 & \\
\hline
\end{tabular}

\section{Joint production by vertical well with fracturing and single- ( $\mathrm{L}$ and $\mathrm{U}$ ) branch horizontal well}

Mode 5 is joint production by vertical well with fracturing and single- ( $\mathrm{L}$ and $\mathrm{U}$ ) branch horizontal well, which is applied in the primary-cataclastic structure coal with the $p_{\mathrm{c}} / p_{\mathrm{i}}$ more than 0.6 and tension stress (e.g. the Fanzhaung 1-well area). Compared the gas rates of fractured vertical well and horizontal well, it could be seen that the gas rates of vertical wells and partial horizontal wells show a satisfactory value (Table 6). Thus, this area should adopt joint production by vertical well with fracturing and single-branch horizontal well with staged fracturing.

Table 6 Comparison of CBM development indexes in the Fanzhuang 1-well area

\begin{tabular}{ccccccc}
\hline $\begin{array}{c}\text { Well } \\
\text { name }\end{array}$ & $\begin{array}{c}\text { Coal } \\
\text { structure }\end{array}$ & $\begin{array}{c}p_{\mathrm{c}} \\
(\mathrm{MPa})\end{array}$ & $\begin{array}{c}p_{\mathrm{c}} / p_{\mathrm{i}} \\
\text { Well 17 }\end{array}$ & $\begin{array}{c}\text { Average gas } \\
\text { rate }\left(\mathrm{m}^{3} / \mathrm{d}\right)\end{array}$ & $\begin{array}{c}\text { Maximum gas } \\
\text { rate }\left(\mathrm{m}^{3} / \mathrm{d}\right)\end{array}$ & Well type \\
Well 18 & 1.71 & $\begin{array}{c}0.7 \\
2\end{array}$ & 4803 & 19556 & $\begin{array}{c}\text { Multi-branch } \\
\text { horizontal well }\end{array}$ \\
Primary- & 1.91 & $\begin{array}{c}0.7 \\
8\end{array}$ & 405 & 1018 & \\
Well 19 & cataclastic & 2.14 & $\begin{array}{c}0.9 \\
1\end{array}$ & 3297 & 7362 & $\begin{array}{c}\text { Vertical well with } \\
\text { fracturing }\end{array}$ \\
\hline
\end{tabular}

\section{Production by single- ( $\mathrm{L}$ and $\mathrm{U}$ ) branch horizontal well with cave completion}

Mode 6 is production by single- ( $\mathrm{L}$ and $\mathrm{U}$ ) branch horizontal well with cave completion, which is applied in the primary-cataclastic structure coal with the $p_{\mathrm{c}} / p_{\mathrm{i}}$ more than 0.6 and extrusion or balance stress or the $p_{\mathrm{c}} / p_{\mathrm{i}} 0.3 \sim 0.6$ (e.g. the Fanzhuang FZ1-well group). Compared the gas rates of vertical and horizontal wells, it could be seen that the gas rate of horizontal well is greater than that of the fractured vertical well (Table 7). Thus, this area should adopt production by single-branch horizontal well with cave completion.

Table 7 Comparison of CBM development indexes in the Fanzhuang FZ1-well group

\begin{tabular}{|c|c|c|c|c|c|c|}
\hline $\begin{array}{l}\text { Well } \\
\text { name }\end{array}$ & $\begin{array}{c}\text { Coal } \\
\text { structure }\end{array}$ & $\begin{array}{c}p_{\mathrm{c}} \\
(\mathrm{MPa})\end{array}$ & $p_{\mathrm{c}} / p_{\mathrm{i}}$ & $\begin{array}{l}\text { Average gas } \\
\text { rate }\left(\mathrm{m}^{3} / \mathrm{d}\right)\end{array}$ & $\begin{array}{l}\text { Maximum gas } \\
\text { rate }\left(\mathrm{m}^{3} / \mathrm{d}\right)\end{array}$ & Well type \\
\hline Well 21 & \multirow{4}{*}{$\begin{array}{l}\text { Primary- } \\
\text { cataclastic }\end{array}$} & 1.43 & $\begin{array}{c}0.3 \\
3\end{array}$ & 536 & 3824 & \multirow{4}{*}{$\begin{array}{l}\text { Multi-branch } \\
\text { horizontal well }\end{array}$} \\
\hline Well 22 & & 1.83 & $\begin{array}{c}0.5 \\
0\end{array}$ & 3648 & 11939 & \\
\hline Well 23 & & 1.35 & $\begin{array}{c}0.3 \\
4\end{array}$ & 165 & 702 & \\
\hline Well 24 & & 1.35 & $\begin{array}{c}0.3 \\
2\end{array}$ & 862 & 2326 & \\
\hline
\end{tabular}

\section{No production at the current stage}

Mode 7 is no production at the current stage, which aims at the primary-cataclastic structure coal with the $p_{\mathrm{c}} / p_{\mathrm{i}}$ less than 0.3 (e.g. the Fanzhuang FZ2-well group). Compared the gas rates of vertical and horizontal wells, it could be seen that both the maximum and average gas rates of horizontal and 
vertical wells are less than $1000 \mathrm{~m}^{3}$ (Table 8). Thus, this area should not develop at the current stage.

Table 8 Comparison of CBM development indexes in the east Fanzhuang FZ2-well group

\begin{tabular}{ccccccc}
\hline $\begin{array}{c}\text { Well } \\
\text { name }\end{array}$ & $\begin{array}{c}\text { Coal } \\
\text { structure }\end{array}$ & $\begin{array}{c}p_{\mathrm{c}} \\
(\mathrm{MPa})\end{array}$ & $p_{\mathrm{c}} / p_{\mathrm{i}}$ & $\begin{array}{c}\text { Average gas } \\
\text { rate }\left(\mathrm{m}^{3} / \mathrm{d}\right)\end{array}$ & $\begin{array}{c}\text { Maximum gas } \\
\text { rate }\left(\mathrm{m}^{3} / \mathrm{d}\right)\end{array}$ & Well type \\
\hline Well 25 & & 1.00 & $\begin{array}{c}0.2 \\
8\end{array}$ & 221 & 597 & $\begin{array}{c}\text { Vertical well with } \\
\text { fracturing }\end{array}$ \\
Well 26 & $\begin{array}{c}\text { Primary- } \\
\text { cataclastic }\end{array}$ & 0.50 & $\begin{array}{c}0.1 \\
8\end{array}$ & 280 & 712 & Multi-branch \\
Well 27 & & 0.55 & 0.11 & 128 & 648 & horizontal well \\
Well 28 & & 0.17 & 0.11 & 448 & 744 & \\
\hline
\end{tabular}

\section{Conclusions}

a. Two types of horizontal wells including single- ( $\mathrm{L}$ and $\mathrm{U}$ ) multi- (V, herringbone and roof) branch are used in the southern Qinshui Basin, among which, the L shape well is worthy of vigorous promotion considering of the low cost, maintainability, and economic space occupation.

b. Under the targets of easier well completion, less pollution, and more benefit, the workflow of well type optimization is: 1) determining the horizontal well development area with the coal structure; 2) extracting the vertical well development area with the vitrinite reflectance in the horizontal well development area; 3 ) determining the horizontal well types and engineering technology modes by considering the $p_{\mathrm{c}} / p_{\mathrm{i}}$ and in situ stresses comprehensively.

c. Seven engineering technology modes are put forward: production by vertical well with fracturing, joint production by vertical well with fracturing and horizontal well with staged fracturing, joint production by single- and multi-branch horizontal well with cave completion, production by multi-branch horizontal well, joint production by vertical well with fracturing and single-branch horizontal well, production by single-branch horizontal well with cave completion, and no production at the current stage.

\section{Acknowledgments}

This work was financially supported by the Key Project of the National Science and Technology (Grant No. 2011ZX05061), the Project of the University-enterprise Cooperation of PetroChina Huabei Oilfield Company "Development optimization design and matching technology optimization in the coalbed methane (CBM) favorable areas, southern Qinshui Basin" (Grant No. HBYT-YJY-2015-JS-300) and the Project of the PetroChina Huabei Oilfield Company "Research on High-Performance Development Technology in Eastern Mabi Block" (Grant No. 2016-HB-M06). We appreciate the constructive comments and suggestions from the reviewers and the editors.

\section{References}

[1] Y. Lv, D. Tang, H. Xu, and H. Luo: Int. J. Coal Geol. Vol. 96-97(2012), p. 93-108

[2] Z. Chen, Y. Wang, J. Yang, X. Wang, Y. Chen, and Q. Zhao: Acta Petrol. Sin. Vol. 30(2009), p. 409-416

[3] S. Liu, S. Sang, M. Li, H. Liu, and L. Wang: J. China Univ. Min. Technol. Vol. 41(2012), p. 943-950

[4] H. Xu, D. Tang, S. Tang, J. Zhao, Y. Meng, and S. Tao: Int. J. Coal Geol. Vol. 121(2014), p. 44-52

[5] B. Xian, C. Chen, X. Wang, and X. Li: China Coalbed Methane Vol. 2(2005), p. 14-17

[6] P. Zhang, M. Zhang: Coal Geol. Explor. Vol. 38(2010), p. 9-13

[7] W. Jiang, J. Ye, and D. Qiao: China Min. Mag. Vol. 19(2010), p. 101-103

[8] S. Liu, N. Hao, and J. Wang: J. China Coal Soc. Vol. 37(2012), p. 957-961 
[9] Q. Meng, Y. Zuo, R. Zhou, Q. Wei, and X. Guo: China Coalbed Methane Vol. 7(2010), p. 14-19 [10] K. Li, Q. Li, Y. Wang, and Y. Qiao: Drilling Prod. Technol. Vol. 29(2006), p. 1-4

[11] S. Cui, F. Wang, S. Liu, L. Zhou, and J. Yu: Nat. Gas Ind. Vol. 31(2011), p. 18-21

[12] L. Wang, Y. Li: J. Henan Sci. Technol. Vol. 1(2013), p. 39-40

[13] J. Zhang, Y. Miao, M. Li, J. Zhang, and L. Zhang: China Petrol. Explor. Vol. 1(2010), p. 49-54

[14] Y. Yang, D. Tang, Y. Yang, L. Chen, and S. Tao: Coal Sci. Technol. Vol. 43(2015), p. 96-99

[15] Y. Li, D. Tang, H. Xu, and T. Yu: J. Petrol. Sci. Eng. Vol. 122(2014), p. 488-496 